\title{
Crises in the Turkish Egg Sector and the Effect of Avian Influenza on the
} Sector

\author{
Gülşen KESKİN*1, Gülzade KAPLAN ${ }^{2}$ \\ ${ }^{1}$ Hatay Mustafa Kemal University, Faculty of Agriculture, Department of Agricultural Economics, 31001, \\ Antakya, Turkey \\ ${ }^{2}$ Republic of Turkey Ministry of Agriculture, Ankara, Turkey
}

Gülşen KESKIN, ORCID No: 0000-0002-4806-0710, Gülzade KAPLAN, ORCID No: 0000-0001-5778-4107

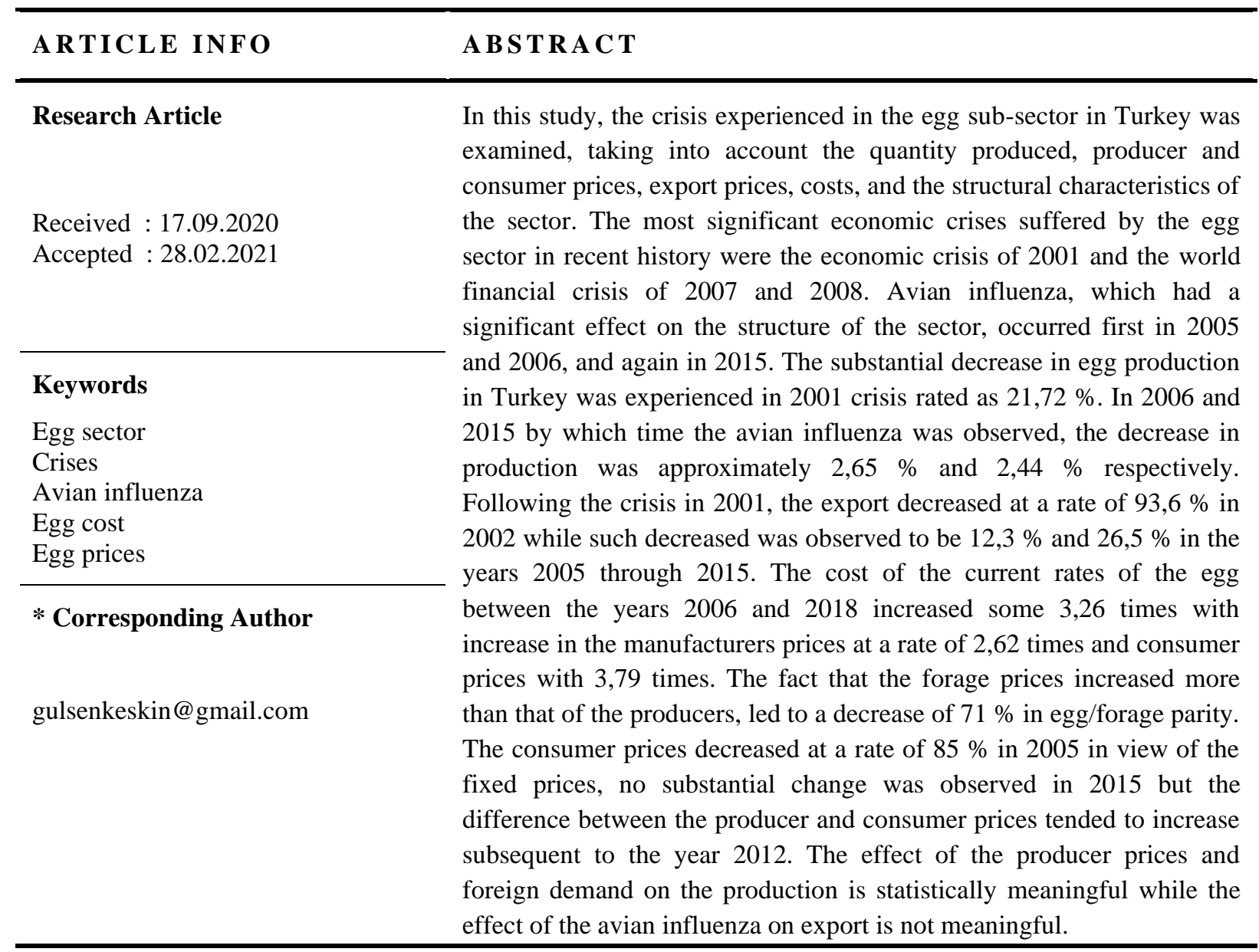

\section{Türkiye'de Yumurta Sektöründe Yaşanan Krizler ve Kuş Gribinin Sektöre Etkisi}

MAKALE BİLGİSI

Araștırma Makalesi

Geliş: 17.09 .2020

Kabul: 28.02.2021
Bu çalışmada, Türkiye'de yumurta alt sektöründe yaşanan krizler; üretim miktarı, üretici-tüketici fiyatları, ihracat fiyatları, maliyetler ve sektörün yapısal özelikleri dikkate alınarak incelenmiştir. Yumurta sektörünün yakın tarihte yaşadığı en önemli ekonomik kriz 2001 yılı finansal krizi ile 2007 ve 2008 yıllarında yaşanan küresel mali krizler olmuştur. Kuş gribi (Avian influenza) ise, sektörün yapılanması 


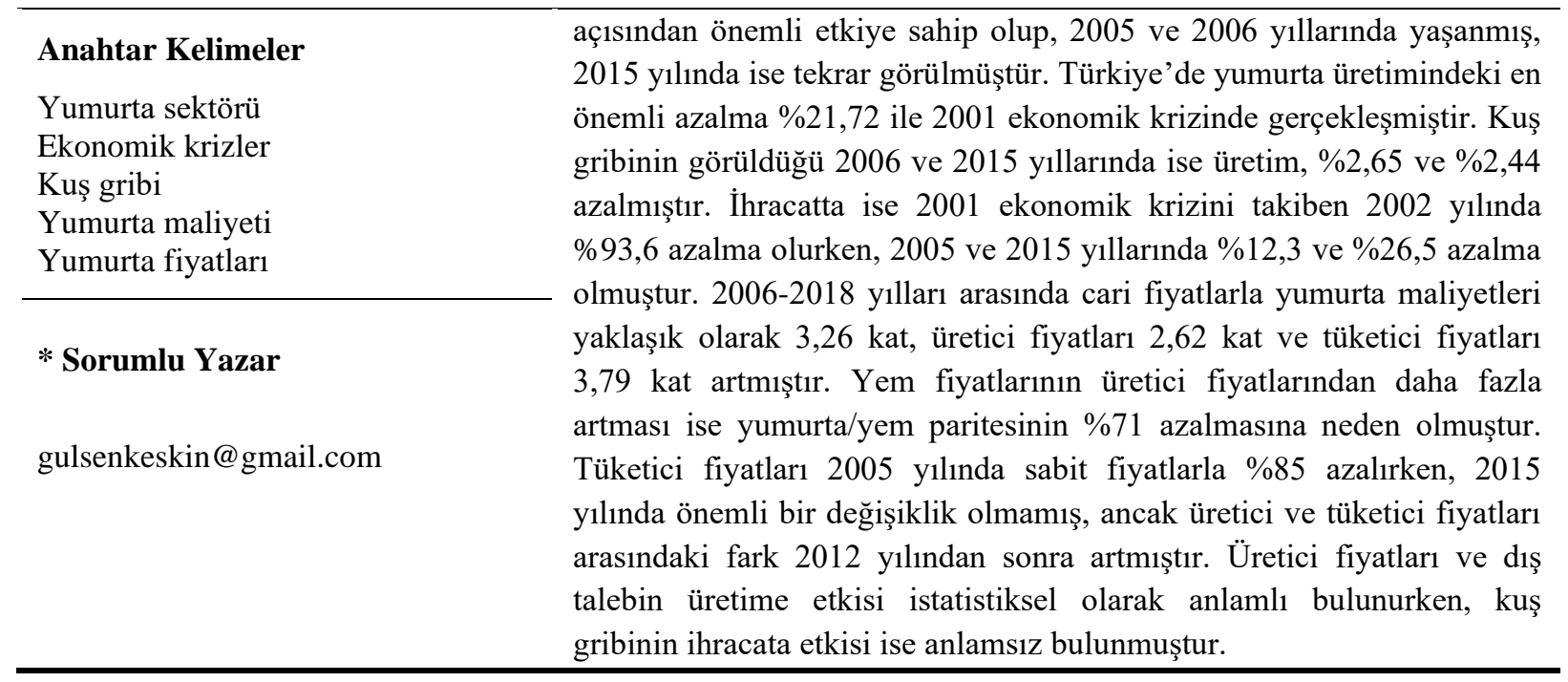

\section{Introduction}

The egg sector in Turkey operates to European standards in modern facilities (TAGEM, 2018). Production in the sector in 1991 was 7,7 billion, and by 2018 this had increased by $150 \%$, reaching 19,6 billion. While the production increase showed a fluctuation, exports increased steadily especially after 2010, attaining a share of $26 \%$ of production. For this reason, along with developments in the internal market, the importance of the economic and political status of trading partner countries has also increased. The increase in production and export has also increased the importance of world trade, and the share of world exports has risen to $16 \%$.

The greatest problem in the Turkish egg sector is that inputs are dependent on other countries (Çiçek and Tandoğan, 2007). In particular, high dependence on other countries for obtaining feed, vaccinations and livestock, which constitute approximately $65 \%$ of costs, show external effects clearly. In addition, the internal dynamics of the sector itself and diseases with a widespread effect such as avian influenza, which affected the whole world, are seen to be significant areas of risk.

The egg sector is one which is most vulnerable to crises of agricultural production, and at different times it has experienced a large number of crises of different origins. Some of these have arisen for political or economic reasons, while others have been crises such as avian flu, which affected animal and human health.

In recent times, in 2001, 2007 and 2008, Turkey suffered economic crises of different origins which affected all sectors of the economy to differing extents (Dellal and Keskin, 2008). While it is possible to follow the reflections of economic crises on agriculture and the sector with variation in the prices of inputs and products (Özdemir et al., 2011), avian flu cases in 2005 for the first time affected the setup of the egg sector in Turkey.

Although the share of export in production is high, the fact that over $70 \%$ of exports are to a single country causes significant congestion in exports following any economic or political problem. For this reason, dependence on other countries on the one hand for raw materials and on the other for export and worldwide risks such as avian flu shows up significant risk areas. 
In this study, an examination was made of the effects of economic crises and avian influenza on the egg sector in Turkey with a description of the general condition of the sector.

\section{Material and Method}

The main material for the study consisted of data from the Turkish Statistics Institute (TUIK), the Ministry of Agriculture and Forestry (TOB), the United Nations Food and Agriculture Organization (FAO), and the Central Association of Egg Producers (YUM-BİR). Studies on the topic and published reports and analyses were also examined as part of the study. First of all, general evaluations relating to the sector were made, and then the effects of crises on the sector were researched. In this regard, the size of production in the egg sector, producer and consumer prices, export prices, producer costs, and layer feed prices were examined. Crises in the sector were examined, taking account of sources from 1992 to 2018. This study made use of the Producer Price Index (PPI) and Consumer Price Index (CPI) and changes in the producer and consumer prices and average of the same spread over the years are made in accordance with the fixed prices. Efforts have been made to make an assessment of the variables which may have an impact on the production and export through regression analysis.

\section{Results and Discussion}

\section{Egg Production in Turkey}

In Turkey, the egg sector had 1.304 businesses in 2006, and 2.715 in 2018. Contrary to this increase in the number of farms, the average number of poultry houses for each farm fell in the same years from 2,5 to 1,8 . The cost of the current rates of the egg between the years 2006 and 2018 increased some 3,26 times with increase in the manufacturers prices at a rate of 2,62 times and consumer prices with 3,79 times. The fact that the forage prices increased more than that of the producers, led to a decrease of $71 \%$ in egg/forage parity (Table 1).

The egg sector in Turkey has certain characteristics such as price fluctuations, prices not being set according to costs, the input/output period for production being long, a short period of eggs remaining on the market (21 days), a lack of development in the egg products industry, sales being paid for in advance or within a short time, and difficulties in planning production in accordance with the market (Sungur, 2014). The dependence of inputs in the sector on other countries and high costs have a negative effect on egg/feed parity and the rate of meeting costs (Table 1).

The consumer prices decreased at a rate of $85 \%$ in 2005 in view of the fixed prices, no substantial change was observed in 2015 but the difference between the producer and consumer prices tended to increase subsequent to the year 2012 (Table 1, Figure 1 and Figure 2). After the outbreak of avian flu experienced by egg producers in 2005, the Egg Producers' Association (YUM-BIR) was created, and a significant increase in exports after 2015 caused the sector to move towards an emphasis on exports. Exports constituted a 1,78\% share of the sector in $1990-1999$; in $2000-2010$ this averaged $4,77 \%$, but rose to $26,13 \%$ in $2011-2018$ (TUIK, 2019). 
Table 1. Significant data on egg production in Turkey

Tablo 1. Türkiye'de yumurta üretimine ait önemli bazı veriler

\begin{tabular}{|c|c|c|c|c|c|c|c|c|}
\hline Year & $\begin{array}{c}\text { Number } \\
\text { of } \\
\text { farms }\end{array}$ & $\begin{array}{c}\text { Number } \\
\text { of } \\
\text { poultry } \\
\text { houses }\end{array}$ & $\begin{array}{c}\text { Producer } \\
\text { price } \\
\text { (TL/egg) }\end{array}$ & $\begin{array}{c}\text { Consumer } \\
\text { price } \\
\text { (TL/egg) }\end{array}$ & $\begin{array}{l}\text { Egg cost } \\
\text { (TL/egg) }\end{array}$ & $\begin{array}{c}\text { Layer } \\
\text { feed } \\
\text { cost } \\
\text { (TL/ton) }\end{array}$ & $\begin{array}{l}\text { Egg/ } \\
\text { feed } \\
\text { parity }\end{array}$ & $\begin{array}{c}\text { Egg } \\
\text { producer } \\
\text { price/cos }\end{array}$ \\
\hline 2006 & 1.304 & 3.284 & 0,1293 & 0,1483 & 0,0923 & 415 & 0,3117 & 1,4010 \\
\hline 2007 & 1.195 & 3.289 & 0,1669 & 0,1957 & 0,0925 & 495 & 0,3371 & 1,8041 \\
\hline 2008 & 1.075 & 3.059 & 0,1899 & 0,1985 & 0,1117 & 628 & 0,3024 & 1,7005 \\
\hline 2009 & 1.078 & 3.120 & 0,2112 & 0,2299 & 0,1213 & 607 & 0,3479 & 1,7408 \\
\hline 2010 & 1.072 & 3.162 & 0,2176 & 0,2096 & 0,1322 & 664 & 0,3278 & 1,6462 \\
\hline 2011 & 1.042 & 3.044 & 0,2368 & 0,2513 & 0,1537 & 807 & 0,2934 & 1,5404 \\
\hline 2012 & 1.050 & 3.243 & 0,2717 & 0,2948 & 0,1622 & 880 & 0,3088 & 1,6753 \\
\hline 2013 & 994 & 3.103 & 0,2151 & 0,3039 & 0,1726 & 945 & 0,2276 & 1,2459 \\
\hline 2014 & 1.046 & 3.141 & 0,2284 & 0,3590 & 0,1928 & 960 & 0,2379 & 1,1845 \\
\hline 2015 & 1.113 & 3.229 & 0,2444 & 0,3900 & 0,1979 & 1.100 & 0,2222 & 1,2348 \\
\hline 2016 & 1.698 & 3.616 & 0,2498 & 0,3768 & 0,2027 & 1.067 & 0,2341 & 1,2324 \\
\hline 2017 & 2.053 & 4.025 & 0,2717 & 0,4454 & 0,2318 & 1.220 & 0,2227 & 1,1722 \\
\hline 2018 & 2.715 & 5.066 & 0,3400 & 0,5624 & 0,3013 & 1.536 & 0,2214 & 1,1284 \\
\hline
\end{tabular}

Sources: YUM-BİR, 2020; TOB, 2019.

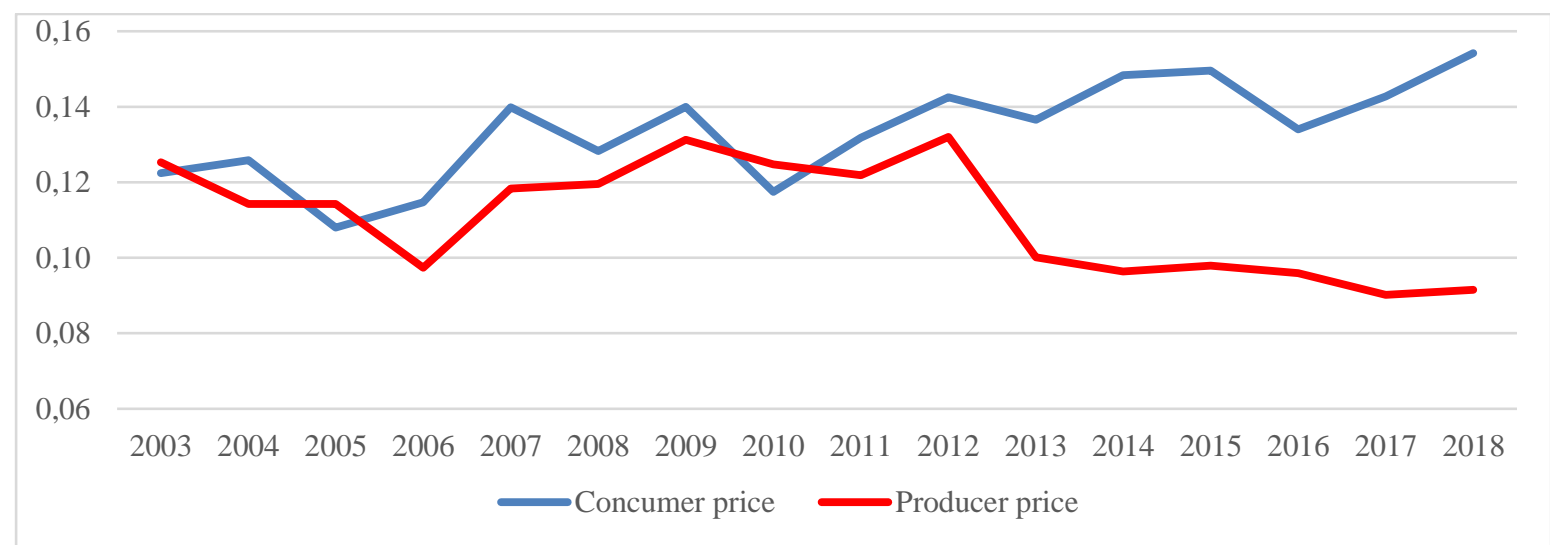

Figure 1. Variation in consumer and producer prices $(2003=100)$

Şekil 1. Üretici ve tüketici fiyatlarındaki değişim $(2003=100)$ 


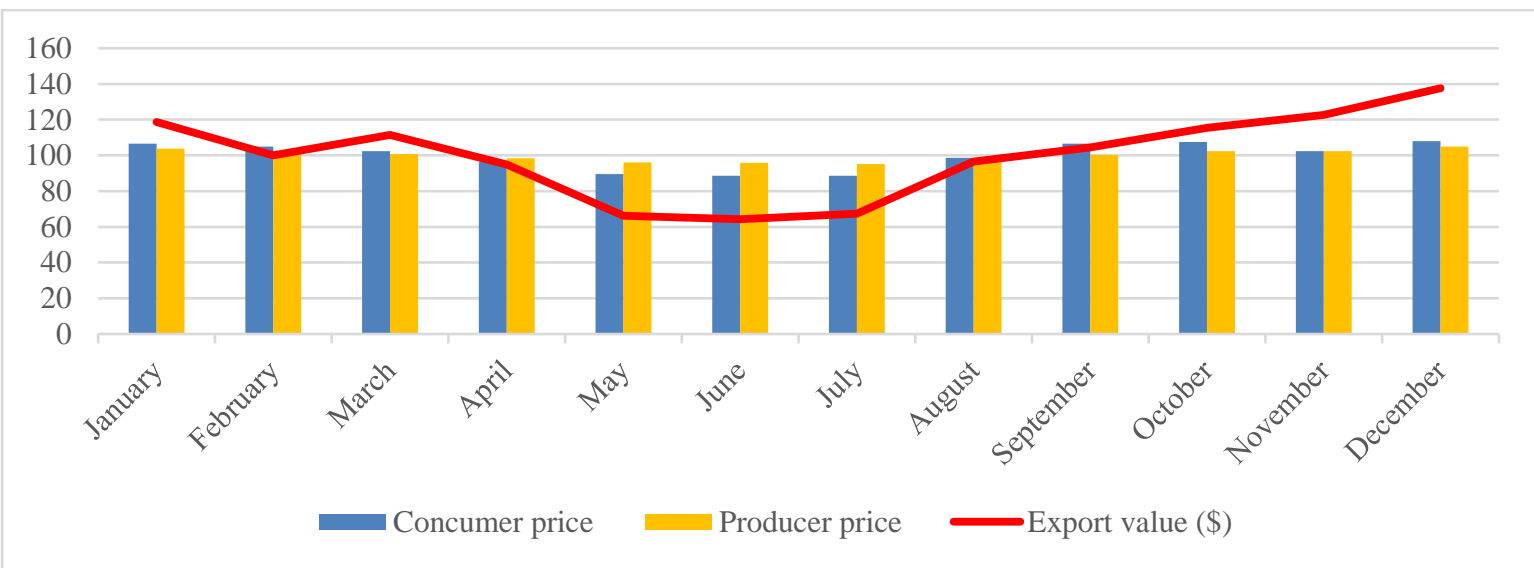

Figure 2. Variation in long-term average chicken egg prices (2003-2019)

Şekil 2. Uzun yıllar ortalamasına göre tavuk yumurtası fiyatlarındaki değişim (2003-2019)

Examining long-term average producer prices as an indicator of the economic sustainability of production, it is seen that from April to August producer prices are lower than consumer prices, as shown in Figure 2. These are months in which export income is also seen to be low. Producer prices being above consumer prices for two thirds of the year puts pressure on the sector.

\section{Crises in the Sector and their Effects}

Chicken egg production increased by $150 \%$ between 1991 and 2018, reaching 19,6 billion in 2018. In this period, annual average production was 13,1 billion. Production increased significantly, particularly after 2012; it did not fall below 16-17 billion, and remained above the long-term average. Other periods when production was above the longterm average were 1998-2000 and 2009 (Figure 3). In 2010, the sector was brought to crisis point by an increase in feed costs, unplanned growth, and a fall in egg prices on internal and external markets (YUM-BIR, 2020). With the expectation of high profits and a constant increase in egg production in Turkey, it is frequently seen in Turkey in times of crisis that large producers collapse and businesses change hands.

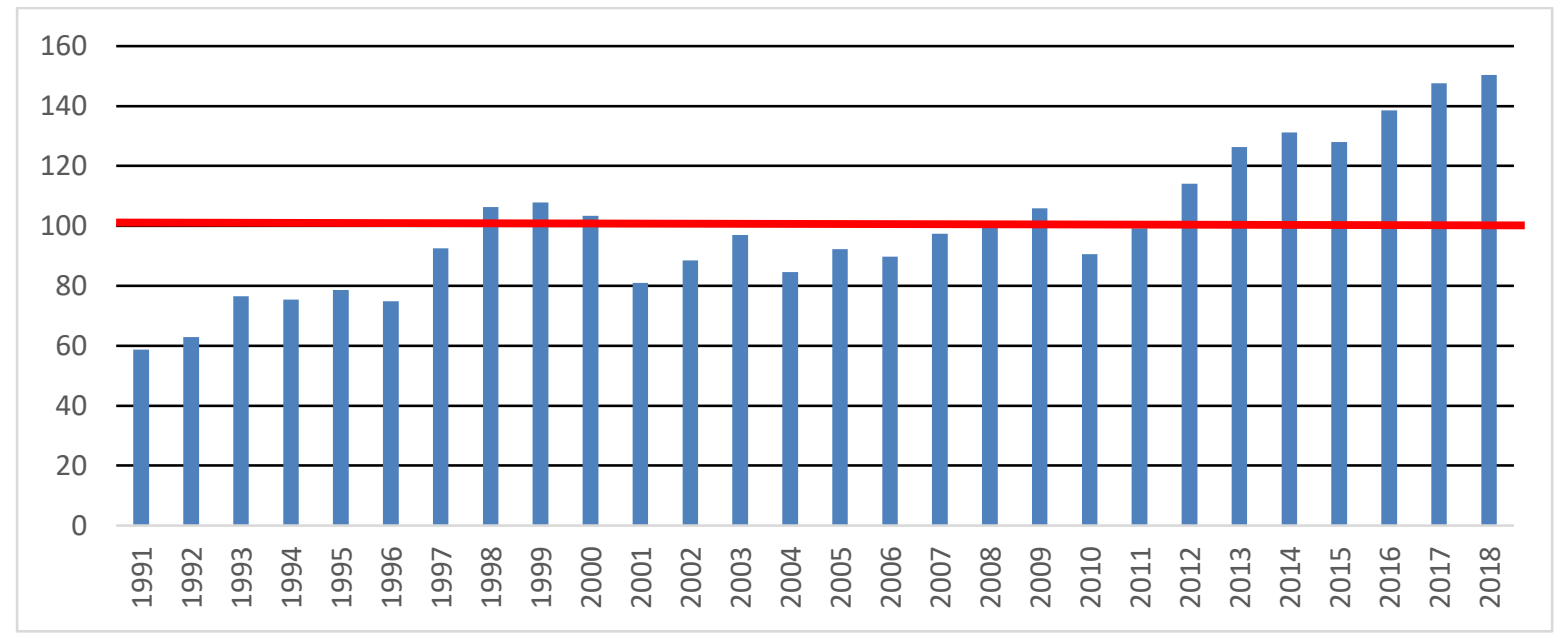

Figure 3. Egg production according to the long-term average (1992-2018)

Şekil 3. Uzun yıllar ortalamasına göre yumurta üretimindeki değişim (\%)

Hayvan Bilimi ve Ürünleri Dergisi / Journal of Animal Science and Products (JASP) 
The poultry sector in Turkey was affected at different levels by eight crises between 1992 and 2018 (Figure 4 and Figure 5). The economic crises of 1994, 1996, 2000 and 2004 in the sector caused significant falls in egg production. The substantial decrease in egg production in Turkey was experienced in 2001 crisis rated as 21,72\%. In 2006 and 2015 by which time the avian influenza was observed, the decrease in production was approximately $2,65 \%$ and 2,44 \% respectively. Following the crisis in 2001, the export decreased at a rate of $93,6 \%$ in 2002 while such decreased was observed to be $12,3 \%$ and $26,5 \%$ in the years 2005 and 2015 (Figure 4 and Figure 5). In particular, the financial crisis which began in January 2001 deeply affected the poultry sector, as it did all sectors. However, a basic structural change occurred in the sector after the outbreak of avian flu in 2005. After avian flu, which had an effect on a global scale, the sector underwent restructuring and was organised under the umbrella of the Central Association of Egg Producers (YUM-BİR) (Haghıghı, 2010; Özlü and Türkoğlu 2020). Currently, 12 associations are active under the aegis of YUM-BİR with 400 producing members in regions where there is intensive egg production (YUM-BIR, 2020).

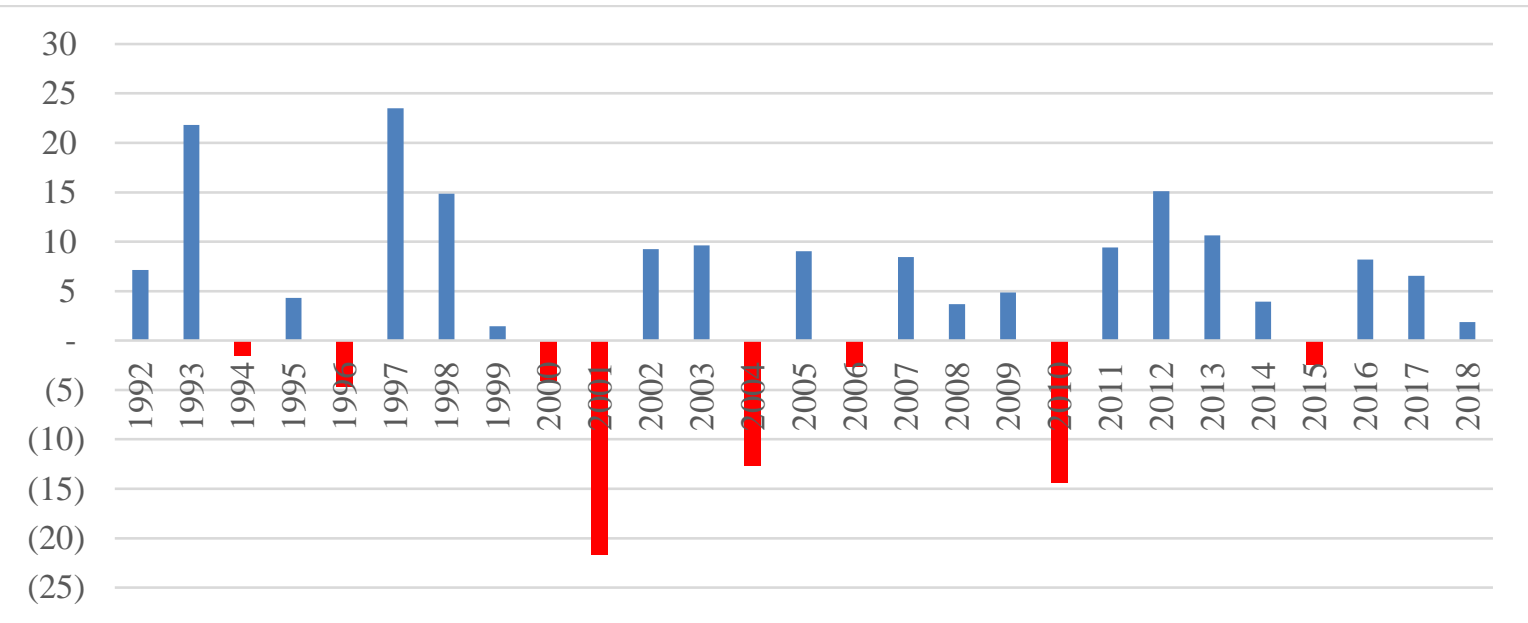

Figure 4. Changes in chicken egg production in the crisis years (\%)

Şekil 4. Kriz yıllarında tavuk yumurtası üretimindeki değişim (\%)

Turkey experienced two outbreaks of avian flu, in 2005-2006 and in 2015. In the first crisis, the sector did not have an organisation, and along with misinformation, this caused a significant drop in consumption. In 2015 both the sector and the public were better informed, and there was a more common sense approach. During each of these crises, production in the sector fell by approximately $2,5 \%$, but the economic crises affected the sector more deeply (Figure 4). 




Figure 5. Changes in chicken egg exports in the crisis years (\%)

Şekil 5. Kriz yıllarında tavuk yumurtası ihracatındaki değişim (\%)

The first case of avian flu in Turkey occurred in Northwest Anatolia, and it was quickly brought under control by quarantine and culling methods. Although measures were taken over the whole country, new cases occurred in various regions. For this reason, a newly prepared national pandemic plan began to be implemented, and all relevant ministries, institutions and local administrations were put on alarm status. Also, the necessary precautions were taken to prevent the spread of the disease, with civil society organizations and the private sector working together. The National Committee for Zoonotic Diseases, the National Centre for Disease Control and disease control centres at a local level were set up. The pandemic plan was updated and implemented, with periodic reviews (Sarnıç, 2006).

In order to create a high level of awareness, to maintain preparedness and to provide environmental protection, the Agriculture Ministry in 2010 prepared an emergency action plan to identify necessary national measures and to implement them against any possible outbreak of disease (TOB, 2010). Precautions taken at the national level were effective in protecting against avian flu and the fight against the disease. At the same time, there was a widespread view among consumers that after the culling of poultry, there had been an increase in the ticks which cause Crimean Congo Haemorrhagic Fever (Akgül, 2011). This view was affected by the fact that cases of tick bite are common in rural areas; however, they are not as dangerous as the cases of avian flu.

As the sector most affected by infectious diseases, the poultry sector can suffer great economic losses, and whole flocks can be lost at a stroke. The losses of the sector are not limited to the loss of livestock, but also buildings remain empty, production is lost, and prevention and protection costs are incurred (Akan, 2006). Avian flu is a global problem, and is a factor limiting the development of the sector in terms of both production and growth (TAGEM, 2018).

While the factors of producer prices $(\mathrm{P}<0.01)$ and demand $(\mathrm{P}<0.01)$ affecting production were found to be statistically significant, the effect of avian flu and the economic crises were found not to be statistically significant ( $\mathrm{P}>0.10$; DW 1.572; F 43.772; VIF<5). The effect of avian flu on exports was found to be statistically non-significant $(\mathrm{P}>0.10)$, but the economic crises were found to be significant $(\mathrm{P}<0.10)$. However, in the export model, the 
representative power of the model was rated as weak (DW 0.990; F 23.064; VIF<5).

\section{Conclusions}

The substantial decrease in egg production in Turkey was experienced in 2001 crisis rated as 21,72\%. In 2006 and 2015 by which time the avian influenza was observed, the decrease in production was approximately $2,65 \%$ and $2,44 \%$ respectively. Following the crisis in 2001, the export decreased at a rate of $93,6 \%$ in 2002 while such decreased was observed to be $12,3 \%$ and $26,5 \%$ in the years 2005 and 2015 . The cost of the current rates of the egg between the years 2006 and 2018 increased some 3,26 times with increase in the manufacturers prices at a rate of 2,62 times and consumer prices with 3,79 times. The fact that the forage prices increased more than that of the producers, led to a decrease of $71 \%$ in egg/forage parity. The consumer prices decreased at a rate of $85 \%$ in 2005 in view of the fixed prices, no substantial change was observed in 2015 but the difference between the producer and consumer prices tended to increase subsequent to the year 2012. The effect of avian flu on internally and externally caused financial crises of production and export were found not to be statistically significant $(\mathrm{P}>0.10)$.

It is necessary to reduce dependence on other countries for raw materials, and in particular to move to a situation where feed requirements can be met from inside the country and by the farms themselves. In this way, it will be possible to reduce production costs to reasonable levels, and price fluctuations will be reduced.

In order to remove dependence on a small number of countries for exports, it is important for the sustainability of external trade to find new markets. Also, product diversification will enliven exports.

One of the chronic problems faced by the sector is that firms producing in the sector are constantly changing hands. This is because production continues with a firm which makes large sales at one time disappearing later, and another taking its place.

Avian flu, which is one of the global crises faced by the sector, is one of the factors affecting production, consumption and external trade. However, the sector combatting this problem in an organised way, informing the public and behaving openly have avoided panic even in years when there was fear of avian flu.

\section{References}

Akan, M. 2006. Kümes hayvanlarında kuş gribi. Available from: http://www.floradergisi.org. Accessed:.Jan.29.2020.

Akgül, H.C. 2011. Öğretmen adaylarının tarım kaynaklı güncel kavramlar hakkındaki farkındalıklarının tespiti. Mersin Üniversitesi Eğitim Fakültesi Dergisi 7(1):59-68.

Çiçek, H. and M. Tandoğan, 2007. Türkiye'de ticari yumurta fiyatları ve etkili faktörler. Tavukçuluk Araştırma Dergisi 7 (1): 46-51.

Dellal, İ. and G. Keskin, 2008. Küresel Mali Kriz: Tarım Sektöründe Riskler ve Fırsatlar. TEAE Yayın No: 170, Ankara, pp.44-65

Haghıghı, E. 2010. Türkiye'nin Orta Doğu Ülkeleri ile Yumurta Pazarlaması ve Geliştirme Olanakları. A.Ü. Fen Bilimleri Enstitüsü. Yüksek Lisans Tezi, Ankara. 
Özdemir, G., G. Keskin and H. Özüdoğru, 2011. Türkiye'de ekonomik krizler ve tarımsal kooperatiflerin önemi. Journal of Tekirdag Agricultural Faculty 8(1): 101-113.

Özlü, S. and M. Türkoğlu, 2020. Kanatlı hayvan sektöründe mevcut durum ve gelecek. Türkiye Ziraat Mühendisliği IX. Teknik Kongresi Bildiriler Kitabı-2, TMMOB Ziraat Mühendisleri Odası, 13-17 Jan, Ankara, p 155.

Sarnıç, M. 2006. Avian Influenza (Kuş Gribi) hastalığının Türk ekonomisi üzerindeki etkileri. Uluslararası Ekonomik Sorunlar Dergisi XXII. Available from: www. http://www.mfa.gov.tr/avian-influenza-_kus-gribi_-hastaliginin-turk-ekonomisiuzerindeki-etkileri-.tr.mfa. Accessed:.Jan. 01.2020.

Sungur, H. 2014. Türk yumurta sektörü: Üretim-tüketim-ihracat. Available from: www.yumbir.org. Accessed: Dec.20.2019.

TAGEM, 2018. Kanatlı Hayvancılık Sektör Politika Belgesi 2018-2022, Tarım ve Orman Bakanlığ 1 , Ankara, pp 6-80.

TOB, 2010. Avian İnfluenza Hastalığı Acil Eylem Planı. Tarım ve Orman Bakanlığı, Koruma Kontrol Genel Müdürlügü, Ankara, pp 7-15.

TOB, 2019. Tarım ve Orman Bakanlığı, Hayvancılık Genel Müdürlüğü Verileri. Ankara, Available from : www.tarimorman.gov.tr. Accessed: Jan.15.2020.

TUIKK, 2019. Diş ticaret istatistikleri. Available from: www.tuik.gov.tr. Accessed: Dec.15.2019.

YUM-BİR, 2020. Yumurta üreticileri merkez birliği verileri. Ankara. Available from : www.yum-bir.org. Accessed: Dec.06.2020. 